\title{
Endocrine changes and liver mRNA abundance of somatotropic axis and insulin system constituents during negative energy balance at different stages of lactation in dairy cows
}

\author{
J. Gross, ${ }^{*}$ H. A. van Dorland,† F. J. Schwarz, ${ }^{\star}$ and R. M. Bruckmaiert ${ }^{1}$ \\ *Department of Animal Sciences, Chair of Animal Nutrition, Technical University of Munich, Liesel-Beckmann-Str. 6, \\ D-85350 Freising-Weihenstephan, Germany \\ †Veterinary Physiology, Vetsuisse Faculty, University of Bern, Bremgartenstr. 109a, CH-3001 Bern, Switzerland
}

\begin{abstract}
The liver has an important role in metabolic regulation and control of the somatotropic axis to adapt successfully to physiological and environmental changes in dairy cows. The aim of this study was to investigate the adaptation to negative energy balance (NEB) at parturition and to a deliberately induced NEB by feed restriction at 100 days in milk. The hepatic gene expression and the endocrine system of the somatotropic axis and related parameters were compared between the early and late NEB period. Fifty multiparous cows were subjected to 3 periods $(1=$ early lactation up to $12 \mathrm{wk}$ postpartum, 2 = feed restriction for $3 \mathrm{wk}$ beginning at around 100 days in milk with a feedrestricted and a control group, and $3=$ subsequent realimentation period for the feed-restricted group for $8 \mathrm{wk})$. In period 1, plasma growth hormone reached a maximum in early lactation, whereas insulin-like growth factor-I (IGF-I), leptin, the thyroid hormones, insulin, and the revised quantitative insulin sensitivity check index increased gradually after a nadir in early lactation. Three days after parturition, hepatic mRNA abundance of growth hormone receptor 1A, IGF-I, IGF-I receptor and IGF-binding protein-3 (IGFBP-3) were decreased, whereas mRNA of IGFBP-1 and -2 and insulin receptor were upregulated as compared with wk 3 antepartum. During period 2, feed-restricted cows showed decreased plasma concentrations of IGF-I and leptin compared with those of control cows. The revised quantitative insulin sensitivity check index was lower for feed-restricted cows (period 2) than for control cows. Compared with the NEB in period 1, the changes due to the deliberately induced NEB (period 2 ) in hormones were less pronounced. At the end of the 3 -wk feed restriction, the mRNA abundance of IGF-I, IGFBP-1, $-2,-3$, and insulin receptor was increased as
\end{abstract}

Received February 8, 2011.

Accepted March 13, 2011

${ }^{1}$ Corresponding author: rupert.bruckmaier@vetsuisse.unibe.ch compared with the control group. The different effects of energy deficiency at the 2 stages in lactation show that the endocrine regulation changes qualitatively and quantitatively during the course of lactation.

Key words: negative energy balance, somatotropic axis, hormone, liver

\section{INTRODUCTION}

At the onset of lactation, nutritional and energetic requirements can increase 4-fold in high-yielding dairy cows within 1 day (Carriquiry et al., 2009). The demands for nutrients and energy cannot be met during early lactation because feed intake after parturition increases more slowly than the energetic output required by milk production. Dramatic endocrine changes occur during the transition period from late pregnancy to lactation in dairy cows to regulate the required metabolic changes.

In response to the energy deficiency, mobilization of body fat and muscle tissue occurs. The orchestrated changes in adaptation mechanisms of body tissues toward the new physiological state of priority (Bauman and Currie, 1980) - the lactation - are mediated by members of the somatotropic axis and other hormones. A pivotal role in this homeorhetic control of metabolism is played by growth hormone (GH), mainly mediated via IGF-I. Growth hormone directly acts on liver and adipose tissue (e.g., increases gluconeogenesis and decreases lipogenesis) as well as acting indirectly through IGF-I and IGF-binding proteins (IGFBP) on muscle and mammary gland (e.g., increases utilization of NEFA and increases mammary blood flow; reviewed by Renaville et al., 2002). The family of IGFBP binds circulating IGF-I and modulates its distribution and interaction with IGF-I receptors within target tissues (Renaville et al., 2002).

Simultaneously, early lactation in dairy cows is characterized by a hypoinsulinemic state. Contrary to the insulin-independent nutrient uptake in the mammary gland, low plasma insulin concentrations induce an 
increased oxidation of fatty acids, decreased glucose oxidation and uptake of glucose in insulin-responsive tissues (Butler et al., 2003) thus saving glucose for lactose synthesis in the mammary gland. Besides insulin and the GH-IGF-I axis, leptin (Liefers et al., 2003) and the thyroid hormones (Blum et al., 1983) play an important role in the regulation of metabolic activity during the lactational NEB and interact with other endocrine systems (Chilliard et al., 2005).

Different effects of an NEB at 2 stages in lactation (NEB in early lactation and a deliberately induced NEB by feed restriction at 100 DIM) on performance parameters and metabolites in dairy cows have been described elsewhere (Gross et al., 2011). Changes in plasma metabolites during the deliberately induced NEB were less than those occurring during the NEB in early lactation, despite the extent of the induced NEB being even higher when compared with the NEB in early lactation. In the present study, the regulation of metabolism by the somatotropic axis during these 2 periods of energy deficiency was compared and quantified based on plasma hormone concentrations and mRNA expression of related genes and receptors in the liver. The hypothesis was tested that the adaptation to NEB at parturition and to a deliberately induced NEB by feed restriction at 100 DIM is differently regulated.

\section{MATERIALS AND METHODS}

\section{Animal Trial}

The animal trial was carried out at the Agricultural Experimental Unit Hirschau of the Technical University Munich, Germany, and was approved by the state department for animal welfare affairs. The study included 50 multiparous Holstein dairy cows $(3.2 \pm 0.2$ parities, mean \pm SEM) and covered the period from wk 3 antepartum (a.p.) to approximately wk 26 postpartum (p.p.).

In experimental period 1 (wk 3 a.p. up to 12 p.p.), all cows were treated similarly. In period 2 , at around 100 DIM, animals were allocated equally to either a control (C) or a restriction group (R) according to their NEB in early lactation. Each group consisted of 25 cows, and the feed restriction lasted for $3 \mathrm{wk}$. The week before feed restriction was designated as wk 0 . To induce an energy deficiency of at least $30 \%$ of cow requirements at the start of period $2, \mathrm{R}$ cows received a limited amount of feed from a similar diet as the $\mathrm{C}$ cows, but mixed with additional hay, and a decreased amount of concentrate. After 3 wk of feed restriction and established NEB, period 3 started, where R cows were (re)fed similarly as $\mathrm{C}$ cows for $8 \mathrm{wk}$. The feeding regimen and NEB was recently described in more detail (Gross et al., 2011).

\section{Blood Collection and Analyses of Hormones and Metabolites}

Blood samples were taken from the jugular vein between $0730 \mathrm{~h}$ and $0900 \mathrm{~h}$ before feeding in wk 3 a.p., wk 1 (on d 3), 2, 4, 8, and 12 p.p., respectively (period 1); weekly during period 2 ; and in wk $1,2,4$, and 8 during period 3 and were immediately cooled down on wet ice and centrifuged for $15 \mathrm{~min}$ at 2,000 $\times \mathrm{g}$. Aliquots of EDTA blood plasma were stored at $-20^{\circ} \mathrm{C}$ until analysis of hormones and metabolites.

Plasma GH, IGF-I, insulin, 3,5,3'-trijodthyronine $\left(\mathbf{T}_{3}\right)$ and thyroxine $\left(\mathbf{T}_{4}\right)$ were measured by radioimmunoassay as described previously Vicari et al. (2008). Plasma leptin was measured by radioimmunoassay with an antibody against bovine leptin kindly provided by Helga Sauerwein, University of Bonn, Germany (Sauerwein et al., 2004). Concentration of plasma glucose was measured using kit no. 61269 from bioMérieux (Genève, Switzerland) and of NEFA with kit no. FA 115 from Randox Laboratories Ltd. (Schwyz, Switzerland). The profiles of glucose and NEFA have been published elsewhere (Gross et al., 2011). In this paper the values are used for the calculation of the revised quantitative insulin sensitivity check index (RQUICKI).

As a measure of insulin sensitivity, the RQUICKI was calculated. The RQUICKI is based on the concentrations of plasma glucose, NEFA, and insulin and may be an instrument to estimate insulin sensitivity in dairy cows (Holtenius and Holtenius, 2007). The RQUICKI is estimated according to the equation given by Perseghin et al. (2001) and used by Holtenius and Holtenius (2007): RQUICKI $=1 /[\log ($ glucose $)+\log ($ insulin $)+$ $\log (\mathrm{NEFA})]$.

\section{Liver Tissue Collection, mRNA Extraction, and Quantitative Real-Time Reverse-Transcriptase PCR}

Liver samples were obtained by blind percutaneous needle biopsy $(14 \mathrm{G} \times 152 \mathrm{~mm}$; Dispomed Witt oHG, Gelnhausen, Germany) under local anesthesia after blood sampling as described by van Dorland et al. (2009) in wk 3 a.p., wk 1 p.p. (on d 3), and wk 4 p.p. (period 1), and before feed restriction in wk 0 and 3 of period 2. Liver tissue (40 to $60 \mathrm{mg}$ ) was put directly into an RNA stabilization reagent (RNAlater; Ambion, Applied Biosystems, Austin, TX), and kept at $+4^{\circ} \mathrm{C}$ for $24 \mathrm{~h}$, and thereafter stored at $-20^{\circ} \mathrm{C}$ until analyzed. Total RNA was isolated from liver tissue using peqGOLD TriFast (PEQLAB Biotechnologie GmbH, 
Table 1. PCR primer information, the annealing temperature, and the PCR product length for the genes analyzed in liver sample ${ }^{1}$

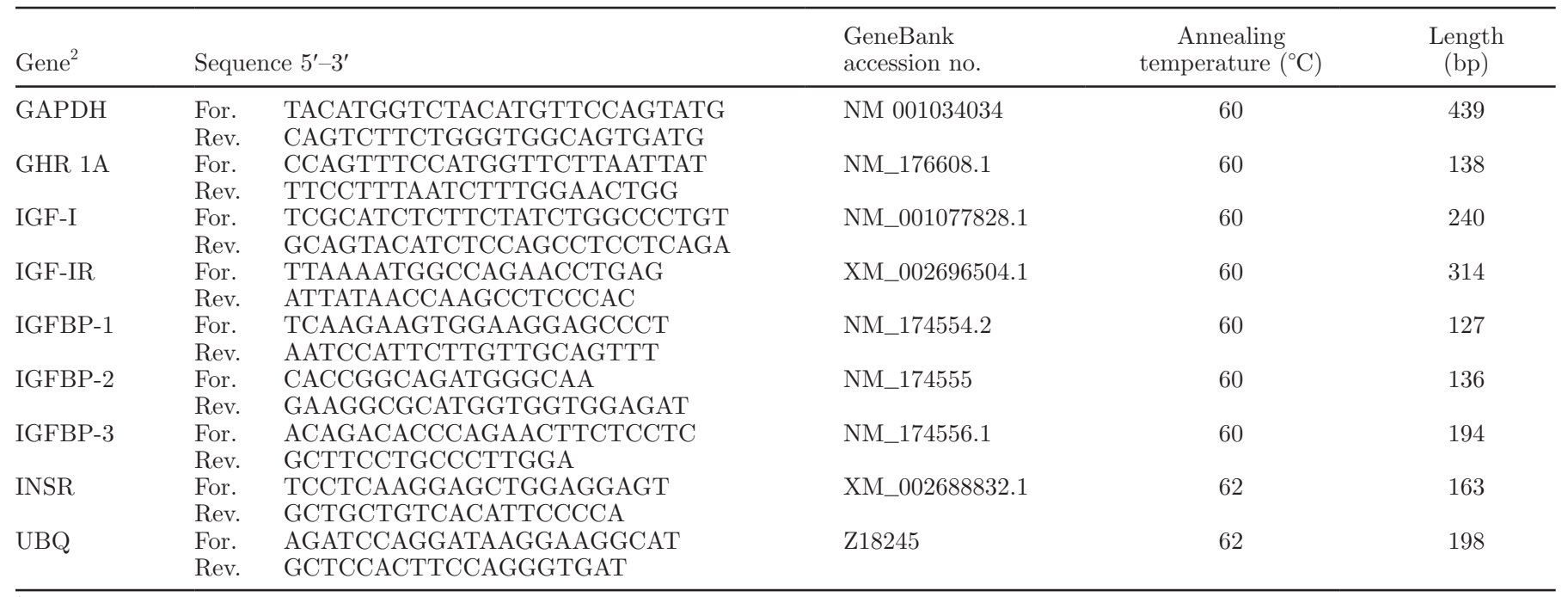

${ }^{1}$ For. $=$ forward; Rev. $=$ reverse.

${ }^{2} \mathrm{GHR} 1 \mathrm{~A}=$ growth hormone receptor $1 \mathrm{~A} ; \mathrm{IGF}-\mathrm{IR}=\mathrm{IGF}-\mathrm{I}$ receptor; IGFBP = IGF-binding protein; INSR = insulin receptor; UBQ = ubiquitin.

Erlangen, Germany) according to the manufacturer's instructions. The yield and purity of total RNA were detected by spectrophotometer with a BioPhotometer (Vaudaux-Eppendorf, Basel, Switzerland). The RNA integrity was verified by the optical density at 260 $\mathrm{nm} / 280 \mathrm{~nm}$ (OD260/OD280) absorption ratio, which was between 1.7 and 2.1 for all samples.

For reverse transcription, $1 \mu \mathrm{g}$ of extracted total RNA was reverse transcribed with $200 \mathrm{U}$ of Moleney Murine Leukemia Virus Reverse Transcriptase RNase H Minus, Point Mutant (Promega Corp., Madison, WI) using 100 pmol of random hexamer primers (Invitrogen, Leek, the Netherlands). The obtained cDNA was diluted to a final concentration of $25 \mathrm{ng} / \mu \mathrm{L}$. The genes selected to measure the expression from the somatotropic axis are described in Table 1. The PCR quantification was performed with the Rotor-Gene 6000 (Corbett Research, Sydney, Australia), using the software version 1.7.40. Fluorescence takeoff was calculated with the second derivative maximum program option. A master mix of the following reaction components was prepared: $1.8 \mu \mathrm{L}$ of diethylpyrocarbonate (DEPC) water, $1.0 \mu \mathrm{L}$ of forward primer $(5 \mathrm{pmol}), 1.0 \mu \mathrm{L}$ of reverse primer $(5 \mathrm{pmol})$, $0.2 \mu \mathrm{L}$ of $50 \times$ SYBR-Green (20 pmol; Applied Biosystems), and $5.0 \mu \mathrm{L}$ of $2 \times$ SensiMix ( $1 \mathrm{mM} \mathrm{MgCl} 2 ; 2 \times$ SensiMix NoRef DNA Kit; Bioline USA, Inc., Taunton, MA). In total, $9 \mu \mathrm{L}$ of master-mix and $1 \mu \mathrm{L}$ of sample volume, containing $25 \mathrm{ng}$ of cDNA, were used. The following 3-step PCR program was used: denaturation for $10 \mathrm{~min}$ at $95^{\circ} \mathrm{C}, 40$ cycles of amplification (each consisting of $15 \mathrm{~s}$ at $95^{\circ} \mathrm{C}$, the primer specific annealing temperature for $30 \mathrm{~s}$ (see Table 1), and extension at $72^{\circ} \mathrm{C}$ for $20 \mathrm{~s}$ and quantification of fluorescence), and finally, a melting curve program $\left(60\right.$ to $\left.95^{\circ} \mathrm{C}\right)$. The mRNA abundance of target genes was calculated relative to the mRNA abundance of the reference genes GAPDH and ubiquitin (UBQ; see Table 1 for details of the primers). The mRNA levels of the housekeeping genes were stable across the time points $(17.7 \pm 0.1$, $17.6 \pm 0.2,17.4 \pm 0.2,17.0 \pm 0.1$ and $17.1 \pm 0.3$ in wk 3 a.p., wk 1 p.p., wk 4 p.p. (period 1), and wk 0 and 3 of period 2 , respectively).

\section{Statistical Analysis}

Data presented in text and figures are means \pm standard error of the means. To identify changes over time within groups, data on mRNA abundance and endocrine parameters at the respective time points of liver biopsies in period 1 [wk 3 a.p., wk 1 p.p. $(=\mathrm{d}$ 3 p.p.), and wk 4 p.p.] and period 2 (wk 0 and 3) were evaluated by a MIXED model in SAS, version 9.2 (SAS Institute, Cary, NC) with time point and parity as fixed effects. Differences over time were detected by the Bonferroni t-test.

To evaluate the effect of feed restriction (period 2) on gene expression in liver, mRNA abundance [delta cycle threshold (CT), $\left.\log _{2}\right]$ in wk 3 of period 2 was evaluated in a MIXED model including group and parity. Furthermore, the mRNA abundance of wk 0 of period 2 was used as a co-variable and individual cow as repeated subject. To evaluate effects of feed restriction on endocrine parameters for periods 2 and 3 (wk 1 to 4), the areas under the curve (AUC) of $\mathrm{R}$ and $\mathrm{C}$ groups were compared using the MIXED procedure of SAS. The model included group and parity as fixed effects. 
The AUC from wk 8 p.p. until the beginning of period 2 (wk 0) was included additionally as a co-variable. The repeated subject was the individual cow. Group differences were detected by the Bonferroni t-test. $P$-values $<0.05$ were considered to be significant.

\section{RESULTS}

\section{Plasma Hormones}

GH, IGF-I, and Leptin. The concentration of plasma GH increased from wk 3 a.p. to a maximum in wk 1 p.p. and then gradually decreased until the start of period 2 (Figure 1A). The plasma GH concentration did not differ between wh 0 and 3 of period 2 in both groups. The AUC of GH during period 2 did not differ between groups. In addition, the GH concentration did not differ in the $\mathrm{R}$ group between wk 1 p.p. (period 1 ) and wk 3 of period 2 . In period 3 , the AUC of GH did not differ between the $\mathrm{R}$ and $\mathrm{C}$ group.

The plasma IGF-I concentration in period 1 decreased from a maximum in wk 3 a.p. to a nadir in wk 2 p.p. and increased steadily thereafter (Figure 1B). The plasma IGF-I concentration did not differ between wk 0 and 3 of period 2 in both groups. The AUC of IGF-I was lower in the $\mathrm{R}$ group than in the $\mathrm{C}$ group during period $2(P<0.05)$. The IGF-I concentration in the $\mathrm{R}$ group did not differ between wk 1 p.p. (period 1) and wk 3 of period 2. In period 3, the AUC of IGF-I did not differ between groups.

The leptin concentration in plasma (Figure 2A) was observed to be highest during period 1 in wk 3 a.p., reached a nadir in wk 1 p.p., and thereafter increased gradually. The plasma leptin concentration did not differ between wk 0 and 3 of period 2 for $\mathrm{R}$ cows. The AUC of leptin was lower in $\mathrm{R}$ cows compared with $\mathrm{C}$ cows during period $2(P<0.05)$. The leptin concentration did not differ between wk 1 p.p. (period 1) and wk 3 of period 2. In period 3, no differences in the AUC of leptin were found between groups.

Insulin and RQUICKI. The insulin concentration in period 1 decreased from wk 3 a.p. to a minimum in wk 1 p.p. and increased thereafter (Figure 2B). For R cows, the insulin concentration differed between wk 0 and 3 of period $2(P<0.05)$. The AUC of insulin did not differ between the $\mathrm{R}$ and $\mathrm{C}$ groups during period 2. The insulin concentration for $\mathrm{R}$ cows was different between wk 1 p.p. (period 1$)$ and wk 3 of period $2(P<$ 0.05 ). In period 3 , no differences were detected for the AUC of insulin between the $\mathrm{R}$ and $\mathrm{C}$ groups.

In period 1, the RQUICKI decreased from wk 3 a.p. to a nadir in wk 2 p.p. and increased gradually thereafter (Figure 2C). Between wk 0 and 3 of period 2, the RQUICKI of $\mathrm{R}$ and $\mathrm{C}$ cows did not differ. The AUC
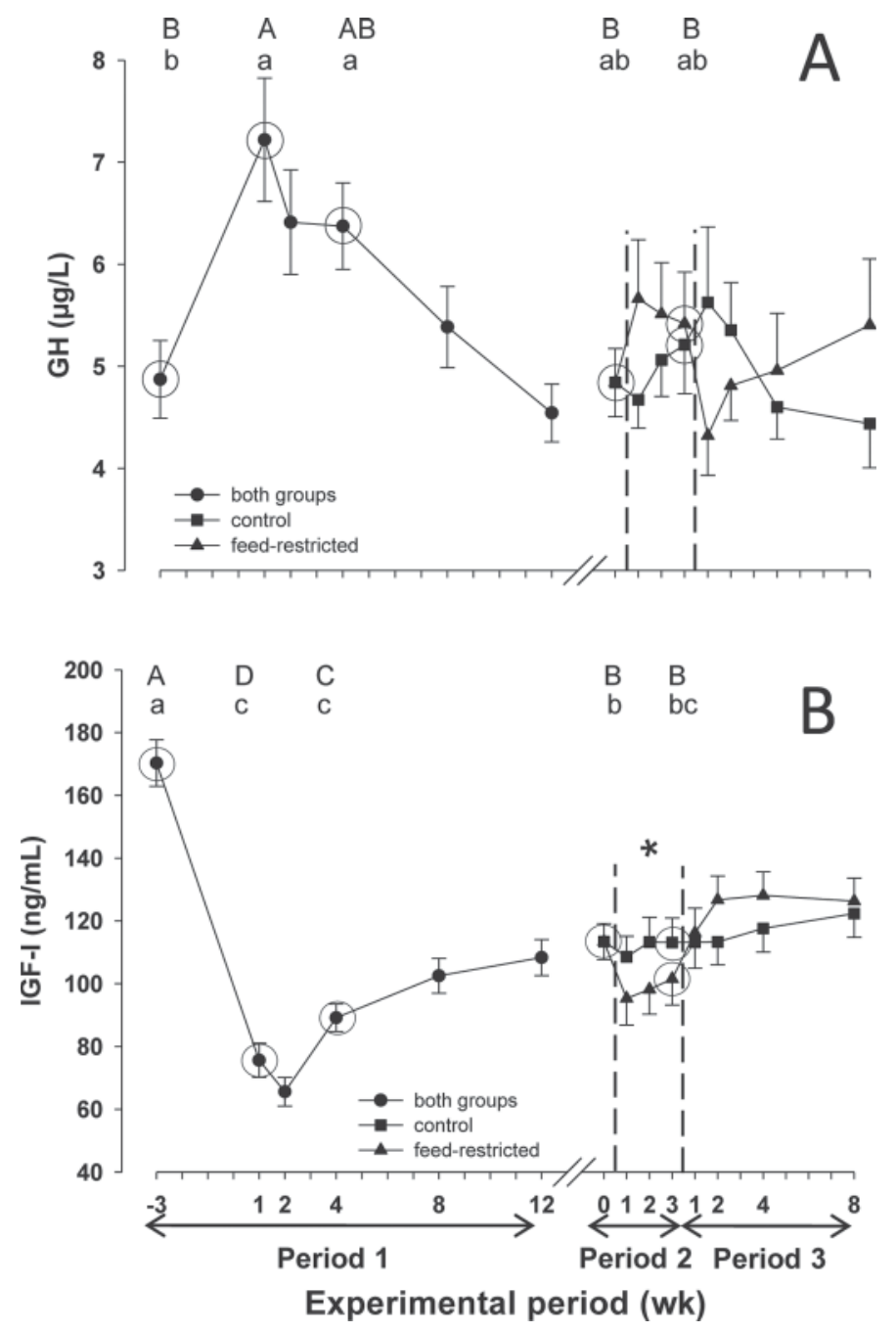

Figure 1. Plasma concentration of growth hormone (GH; A) and IGF-I (B) in cows during experimental period 1 [up to wk 12 postpartum (p.p.)], period 2 (3 wk of feed restriction), and period 3 ( $8 \mathrm{wk}$ of realimentation). Data are given as mean values \pm standard error of the means. Differences between the groups during periods 2 and 3 (wk 1 to 4$)$ are marked with $*(P<0.05)$. Changes over time for points with simultaneous blood and liver samples (in circles) within the groups in period 1 (wk 3 antepartum, wk 1 p.p., wk 4 p.p.) and period 2 (wk 0 and 3) are marked with different letters (A-D for the control group; $\mathrm{a}-\mathrm{c}$ for the feed-restricted group; $P<0.05)$.

of the RQUICKI was lower for R cows compared with $\mathrm{C}$ cows during period $2(P<0.05)$. The $\mathrm{R}$ cows were different in RQUICKI between wk 1 p.p. in period 1 and wk 3 of period $2(P<0.05)$. In period 3 , the AUC of the RQUICKI did not differ between groups.

$T_{3}, T_{4}$, and the $T_{3}: T_{4}$ Ratio. In period 1, the plasma concentration of $\mathrm{T}_{3}$ steadily increased from wk 3 a.p. until the beginning of period 2 (Figure $3 \mathrm{~A}$ ). For $\mathrm{R}$ cows, a difference in $\mathrm{T}_{3}$ concentration between wk 0 and 3 of period 2 was observed $(P<0.05)$, whereas in $\mathrm{C}$ cows, the concentration did not differ. The AUC of $\mathrm{T}_{3}$ did not differ between the $\mathrm{R}$ and $\mathrm{C}$ groups during 

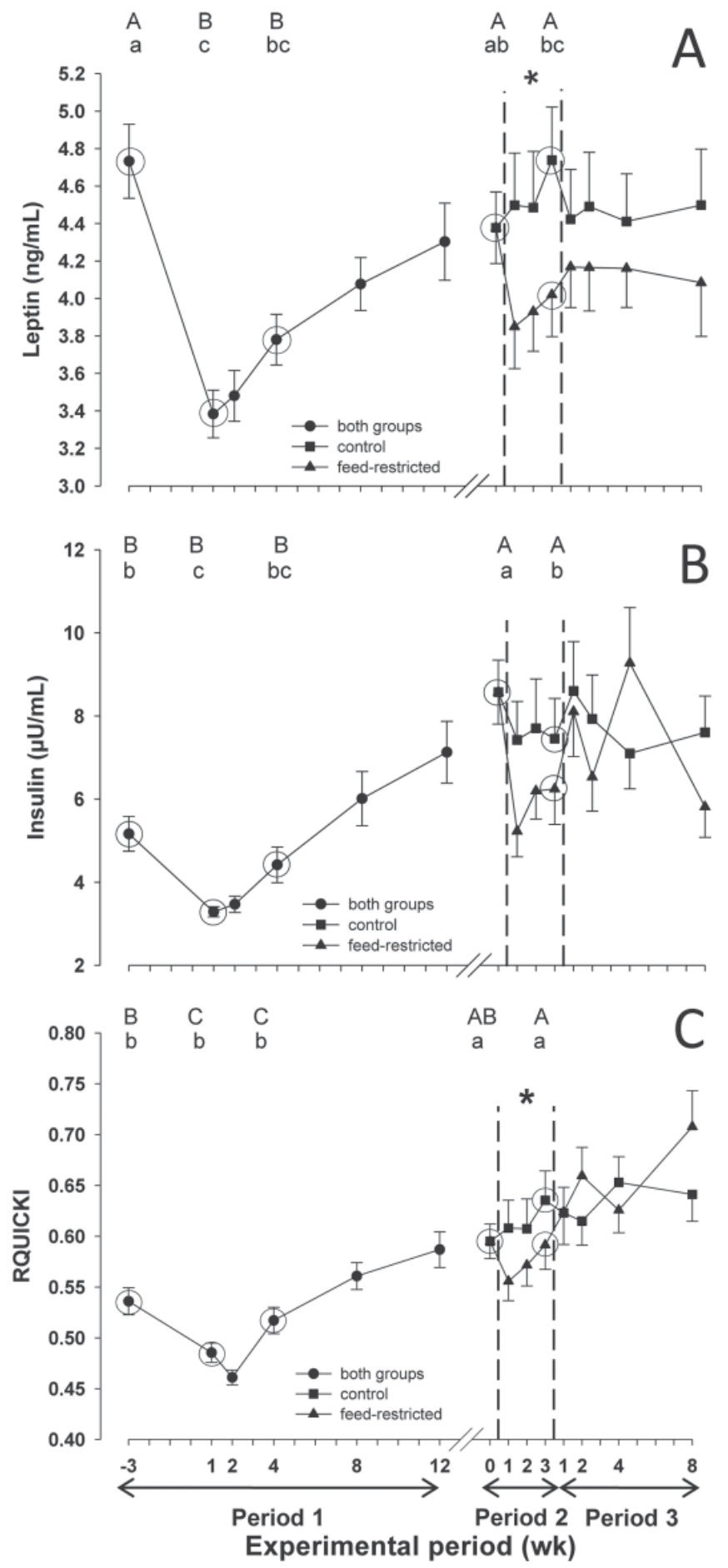

Figure 2. Plasma concentration of leptin (A), insulin (B), and the revised quantitative insulin sensitivity check index (RQUICKI; C) in cows during experimental period 1 [up to wk 12 postpartum (p.p.)], period 2 (3 wk of feed restriction), and period 3 ( $8 \mathrm{wk}$ of realimentation). Data are given as mean values \pm standard error of the means. Differences between the groups during period 2 and 3 (wk 1 to 4 ) are marked with $*(P<0.05)$. Changes over time for points with simultaneous blood and liver samples (in circles) within the groups in period 1 (wk 3 antepartum, wk 1 p.p., wk 4 p.p.) and period 2 (wk 0 and 3 ) are marked with different letters $(\mathrm{A}-\mathrm{C}$ for the control group; $\mathrm{a}-\mathrm{c}$ for the feed-restricted group; $P<0.05)$. period 2. Week 1 p.p. (period 1) and wk 3 in period 2 were not different for $\mathrm{R}$ cows regarding plasma $\mathrm{T}_{3}$ concentration. The AUC of $\mathrm{T}_{3}$ during period 3 did not differ between the $\mathrm{R}$ and $\mathrm{C}$ groups.

In period 1 , the plasma concentration of $\mathrm{T}_{4}$ decreased from wk 3 a.p. to a minimum in wk 1 p.p. and increased thereafter (Figure 3B). For R cows, no difference was found between wh 0 and 3 of period 2. The AUC of $\mathrm{T}_{4}$ did not differ between the $\mathrm{R}$ and $\mathrm{C}$ groups during period 2. The $\mathrm{R}$ cows differed between wk 1 p.p. (period 1$)$ and wk 3 of period 2 in $\mathrm{T}_{4}$ concentration $(P<$ 0.05). In period 3 , no difference in the AUC of the $\mathrm{T}_{4}$ concentration was found between the groups.

In period 1 , the ratio of $\mathrm{T}_{3}: \mathrm{T}_{4}$ increased from the minimum in wk 3 a.p. until wk 1 p.p. (Figure $3 \mathrm{C}$ ) and decreased slightly thereafter. For both $\mathrm{R}$ and $\mathrm{C}$ groups, wk 0 and 3 of period 2 did not differ in the $\mathrm{T}_{3}: \mathrm{T}_{4}$-ratio. In period 2 , the AUC of the $\mathrm{T}_{3}: \mathrm{T}_{4}$-ratio did not differ between the $\mathrm{R}$ and $\mathrm{C}$ groups. Between wk 1 p.p. (period 1) and wk 3 of period $2, \mathrm{R}$ cows showed a difference in the $\mathrm{T}_{3}: \mathrm{T}_{4}$-ratio $(P<0.05)$. In period 3 , no differences were found for the AUC of the $\mathrm{T}_{3}: \mathrm{T}_{4}$-ratio between the groups.

\section{Changes in mRNA Abundance of Hepatic Parameters}

The highest mRNA abundance of growth hormone receptor (GHR) 1A compared with the other time points was measured for $\mathrm{C}$ cows in wk 3 a.p. $(P<$ $0.05)$, whereas $\mathrm{R}$ cows did not show a difference in gene expression over time (Figure 4A). In period 2, no difference was found in mRNA abundance of GHR 1A between wk 0 and 3 for the groups. In wk 3 of period 2 , no differences in gene expression of GHR 1A were found between $\mathrm{R}$ and $\mathrm{C}$ groups. For $\mathrm{R}$ cows, expression of GHR 1A was not different between wk 1 (period 1) and wk 3 of period 2 .

In wk 3 a.p. (period 1), the mRNA abundance of IGF-I was highest compared with wk 1 and 4 p.p. for both $\mathrm{C}$ and $\mathrm{R}$ groups (Figure $4 \mathrm{~B}$ ). The expression of IGF-I did not differ between wk 0 and 3 of period 2 for both groups. In wk 3 of period $2, \mathrm{R}$ cows had a higher mRNA abundance than that of $\mathrm{C}$ cows $(P<$ $0.05)$, which was also higher compared with wk 1 p.p. in period $1(P<0.05)$.

The mRNA abundance of IGF-IR was not affected over time within groups (Figure 4C). Feed restriction (wk 3 in period 2) increased the mRNA abundance of IGF-IR for $\mathrm{R}$ cows compared with $\mathrm{C}$ cows $(P<0.05)$. The gene expression of IGF-IR for $\mathrm{R}$ cows did not differ between wk 1 p.p. of period 1 and wk 3 of period 2 .

The mRNA abundance of IGFBP-1 in period 1 increased from wk 3 a.p. to a maximum at wk 1 p.p. (Figure 5A). No differences were found for IGFBP-1 

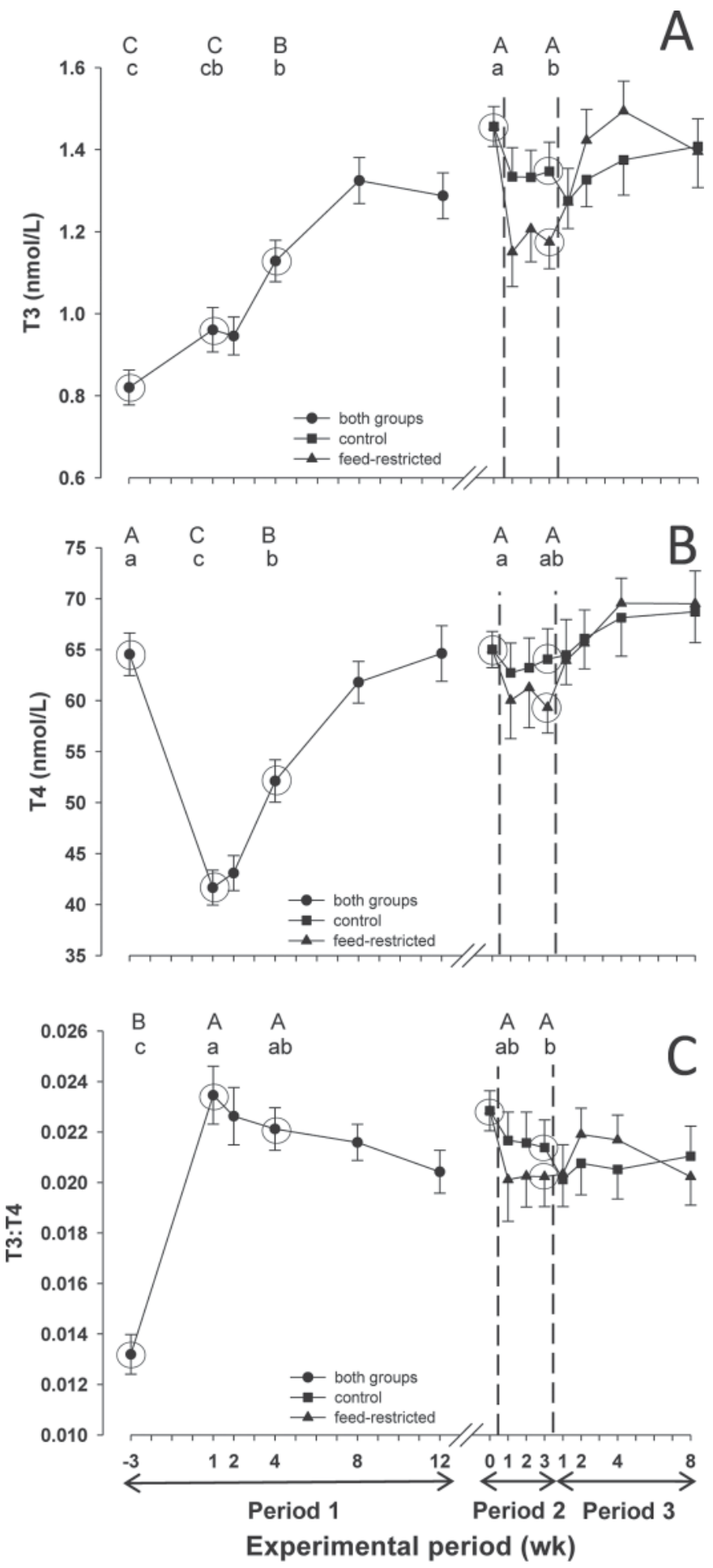

Figure 3. Plasma concentration of 3,5,3'-trijodthyronine $\left(\mathrm{T}_{3} ; \mathrm{A}\right)$, thyroxine $\left(\mathrm{T}_{4} ; \mathrm{B}\right)$, and the $\mathrm{T}_{3}: \mathrm{T}_{4}$ ratio $(\mathrm{C})$ in cows during experimental period 1 [up to wk 12 postpartum (p.p.)], period 2 (3 wk of feed restriction), and period 3 ( $8 \mathrm{wk}$ of realimentation). Data are given as mean values \pm standard error of the means. Changes over time for points with simultaneous blood and liver samples (in circles) within the groups in period 1 (wk 3 antepartum, wk 1 p.p., wk 4 p.p.) and period 2 (wk 0 and 3 ) are marked with different letters $(\mathrm{A}-\mathrm{C}$ for the control group; a-c for the feed-restricted group; $P<0.05$ ). between wk 0 and 3 of period 2 for both $\mathrm{R}$ and $\mathrm{C}$ groups. The $\mathrm{R}$ cows showed a higher mRNA abundance of IGFBP-1 in wk 3 of period 2 compared with $\mathrm{C}$ cows $(P<0.05)$. The expression of IGFBP-1 for $\mathrm{R}$ cows was higher in wk 1 p.p. (period 1) compared with wk 3 of period $2(P<0.05)$.

The mRNA abundance of IGFBP-2 in period 1 increased from wk 3 a.p. to a maximum in wk 1 p.p. for $\mathrm{C}$ and $\mathrm{R}$ cows (Figure 5B) and decreased until wk 0 of period 2. Neither the $\mathrm{R}$ nor the $\mathrm{C}$ group was different in expression of IGFBP-2 between wk 0 and 3 of period 2 . In wk 3 of period $2, \mathrm{R}$ cows had a higher expression of IGFBP-2 than did $\mathrm{C}$ cows $(P<0.05)$. The IGFBP-2 concentration was different in $\mathrm{R}$ cows between wk 1 p.p. (period 1$)$ and wk 3 of period $2(P<0.05)$.

In wk 3 a.p., the mRNA abundance of IGFBP-3 was highest (Figure 5C). The expression of IGFBP-3 was not different for $\mathrm{R}$ and $\mathrm{C}$ groups between wk 0 and 3 of period 2. The $\mathrm{R}$ cows had a higher mRNA abundance of IGFBP-3 in wk 3 of period 2 compared with that of $\mathrm{C}$ cows $(P<0.05)$. For $\mathrm{R}$ cows, no differences were found between wk 1 p.p. (period 1) and wk 3 of period 2.

Expression of the insulin receptor (INSR) in period 1 increased from wk 3 a.p. to a maximum in wk 1 p.p. and decreased thereafter (Figure 6). Between wk 0 and 3 of period 2, no differences were found in expression of the INSR for the $\mathrm{R}$ and $\mathrm{C}$ groups. In wk 3 of period $2, \mathrm{R}$ cows had a higher mRNA abundance of the INSR compared with that of $\mathrm{C}$ cows $(P<0.05)$. For $\mathrm{R}$ cows, the mRNA abundance of the INSR between $\mathrm{d} 3$ p.p. and wk 3 of period 2 did not differ.

\section{DISCUSSION}

The endocrine system mediates essential signals for the successful implementation and maintenance of lactation. Growth hormone and the other constituents of the somatotropic axis contribute markedly in this process during early lactation (Bauman and Currie, 1980; Bradford and Allen, 2008). The increased GH secretion during the NEB p.p. enables the shift of nutrients from body stores toward the mammary gland for milk synthesis (Bauman et al., 1982). The concentration of $\mathrm{GH}$ in the present study was greater during the NEB in early lactation than in the period following the NEB in agreement with Ronge et al. (1988) and Bradford and Allen (2008). A characteristic change we detected during the NEB p.p. was the downregulation of the mRNA abundance of GHR 1A, which is thought to be a key change during the uncoupling of the somatotropic axis in early lactation (Ronge et al., 1988; Lucy et al., 2001; McCarthy et al., 2009). As a consequence of uncoupling, we detected a decreased plasma IGF-I 

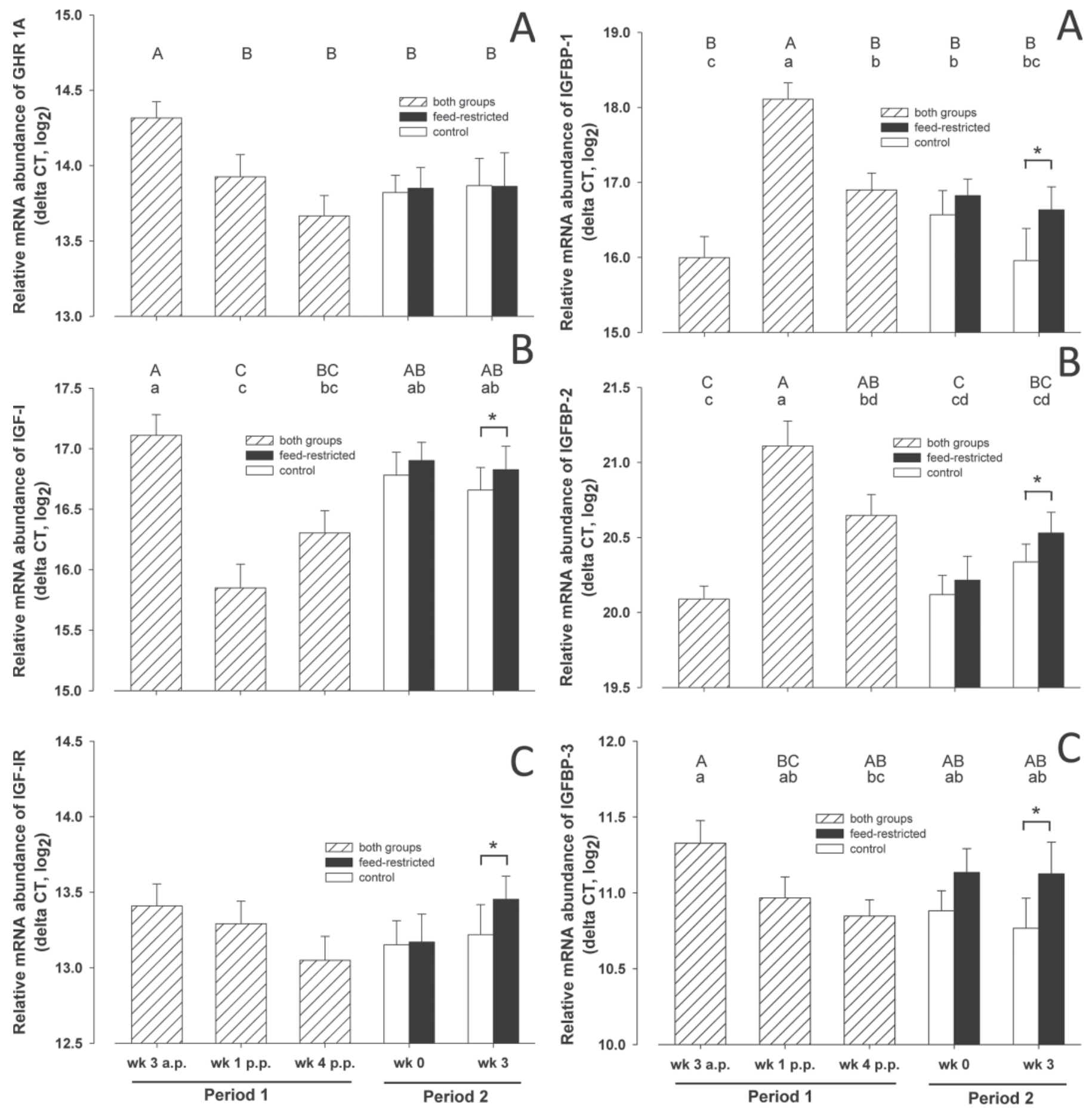

Figure 4. Relative liver mRNA abundance [delta cycle threshold (CT), $\log _{2}$ ] of growth hormone receptor (GHR 1A; A), IGF-I (B), and IGF-I receptor (IGF-IR; C) over the time points in cows during experimental period 1 [up to wk 12 postpartum (p.p.)] and period 2 (3 wk of feed restriction). Data are given as mean values \pm standard error of the means. Effects of feed restriction on mRNA abundance for cows during period 2 are marked with $*(P<0.05)$. Changes over time within the groups in period 1 [wk 3 antepartum (a.p.), wk 1 p.p., wk 4 p.p.] and period 2 (wk 0 and 3 ) are marked with different letters (A-C for the control group; a-c for the feed-restricted group; $P<0.05$ ).

Figure 5. Relative liver mRNA abundance [delta cycle threshold (CT), $\log _{2}$ ] of IGF-binding protein 1 (IGFBP-1; A), IGFBP-2 (B), and IGFBP-3 $(\mathrm{C})$ over the time points in cows during experimental period 1 [up to wk 12 postpartum (p.p.)] and period 2 (3 wk of feed restriction). Data are given as mean values \pm standard error of the means. Effects of feed restriction on mRNA abundance for cows during period 2 are marked with $*(P<0.05)$. Changes over time within the groups in period 1 [wk 3 antepartum (a.p.), wk 1 p.p., wk 4 p.p.] and period 2 (wk 0 and 3 ) are marked with different letters (A-C for the control group; a-d for the feed-restricted group; $P<0.05)$. 


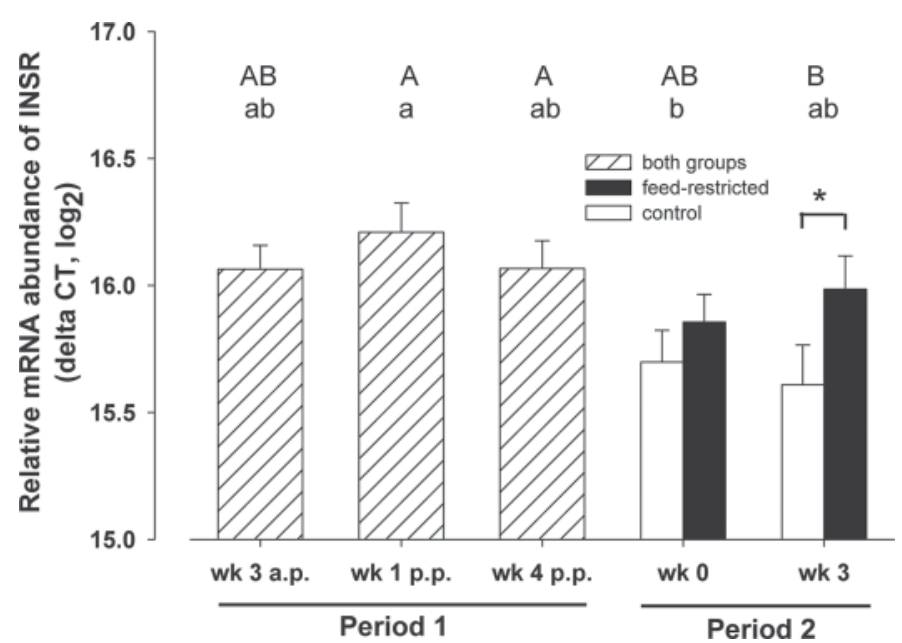

Figure 6. Relative liver mRNA abundance [delta cycle threshold $\left.(\mathrm{CT}), \log _{2}\right]$ of insulin receptor (INSR) over the time points in cows during experimental period 1 [up to wk 12 postpartum (p.p.)] and period 2 (3 wk of feed restriction). Data are given as mean values \pm standard error of the means. Effects of feed restriction on mRNA abundance for cows during period 2 are marked with $*(P<0.05)$. Changes over time within the groups in period 1 [wk 3 antepartum (a.p.), wk 1 p.p., wk 4 p.p.] and period 2 (wk 0 and 3) are marked with different letters (A, B for the control group; a, b for feed-restricted group; $P<0.05$ ).

concentration from wk 3 a.p. until wk 2 p.p., which increased thereafter. These changes reflect the expected differences of hepatic IGF-I synthesis (Kobayashi et al., 1999; Butler et al., 2003; Wook Kim et al., 2004).

The decrease of plasma IGF-I also means a loss of negative feedback of GH secretion and, hence, a lack of inhibition of GH release from the pituitary and provides the explanation of high GH plasma concentrations during catabolic stages (Radcliff et al., 2006).

The responses of plasma GH and IGF-I concentration to the deliberately induced NEB were similar to the NEB p.p., but the changes were less intense. In contrast to NEB in early lactation, feed restriction did not decrease mRNA abundance of GHR $1 \mathrm{~A}$ or of IGF-I, indicating that the endocrine adaptation to the NEB is differently mediated in these 2 periods of NEB. Other cow studies conducted later in lactation (153 to 265 DIM; Kobayashi et al., 2002) showed a decreased mRNA expression of hepatic IGF-I, but mRNA expression of GHR 1A was not changed. In still another study with feed-restricted, but nonlactating dairy cows, decreased plasma IGF-I levels were observed during the period of induced NEB and occurred concomitantly with hepatic decreasing IGF-I mRNA and GHR 1A mRNA abundance. However, no increase in plasma GH level occurred (Meier et al., 2008). These different findings illustrate a variety of different interactions between the key players of the somatotropic axis at different metabolic stages of the animal. Our results indicate a partial uncoupling of the somatotropic axis during the deliberately induced NEB as the plasma IGF-I concentration and hepatic IGF-I mRNA abundance differed between the $\mathrm{R}$ and $\mathrm{C}$ groups, whereas the plasma $\mathrm{GH}$ concentration was not different. The underlying partial $\mathrm{GH}$ resistance of the liver may be related to changes of IGFBP to induce a mechanism for the preferential utilization of mobilized substrates to maintain homeostasis rather than cell growth and proliferation in the feed-restricted animals (Renaville et al., 2002).

A higher mRNA abundance of IGFBP-1 and -2 was observed during the NEB in early lactation and deliberately induced NEB. Insulin-like growth factor-binding protein 1 gene transcription and its glucose counterregulatory role were shown to be elevated during decreased feed intake (Baxter, 1993). Because the expression of IGFBP-1 has been shown to be suppressed by both insulin and IGF-I (Kelley et al., 1996), the low levels of these factors are most likely responsible for the elevated IGFBP-1 mRNA abundance during a NEB. However, metabolic factors also may regulate IGFBP-2 in a manner similar to that of IGFBP-1. Low plasma insulin levels that occur during NEB trigger IGFBP-2 synthesis in the liver (Orlowski et al., 1990; Thissen et al., 1994). The elevation of hepatic IGFBP-2 mRNA abundance during NEB in both lactational stages is consistent with the role of IGFBP to decrease the bioavailability of IGF-I for peripheral tissues (Vicini et al., 1991; Vandehaar et al., 1995; Fenwick et al., 2008). The liver is the main contributor of IGFBP-3 in the circulation and $\mathrm{GH}$ is the main stimulator of IGFBP-3 (Kelley et al., 1996). Whereas the mRNA of IGFBP-3 expression was decreased during the NEB in early lactation, $\mathrm{R}$ cows in the present study showed a higher mRNA abundance of IGFBP-3 during the deliberately induced NEB compared with $\mathrm{C}$ cows. This demonstrates a difference between periods 1 and 2 in the adaptive response to NEB. Changes in IGFBP-1 and -2 during feed restriction appear to restrict the insulin-like activity of IGF-I during catabolic states, but the major decrease of IGFBP-3 likely maximizes the availability of remaining IGF-I to the tissues (Breier, 1999). According to Breier (1999), circulating IGFBP-3 and its ternary complex are decreased during periods of NEB, and the activity of an IGFBP-3-specific protease is induced to decrease IGFBP-3 affinity for IGF-I. However, during the deliberately induced NEB in the present study, the expression of IGFBP-3 did not change when compared with the beginning of feed restriction. Despite decreased circulating IGF-I in R cows, intact ternary complexes of IGF-I and IGFBP-3 appear to be changing, which may alter the interpretation of action. We report low $\mathrm{T}_{3}$ concentrations in the dry period and early lactation, high concentrations of $\mathrm{T}_{4}$ during the 
dry period, and low $\mathrm{T}_{4}$ concentrations in early lactation. The effect of the deliberately induced NEB on thyroid hormones was less pronounced when compared with the NEB in early lactation and for period 1; the results agree with previous reports (Ronge et al., 1988; Pezzi et al., 2003). However, no significant change of $\mathrm{T}_{3}$ and $\mathrm{T}_{4}$ occurred during the feed restriction period as reported by Windisch et al. (1991). Thyroid gland production of $\mathrm{T}_{4}$ is normally transformed into $\mathrm{T}_{3}$ by 5 -deiodination in the liver, but the deiodinating system is also present in other peripheral tissues that produce $\mathrm{T}_{3}$ according to the local requirements (Pezzi et al., 2003). The increased utilization of thyroid hormones by the mammary gland or the altered $5^{\prime}$-deiodinase activity in the liver are partly responsible for the hypothyroid state in early lactating animals. The hypothyroid state enhances mammary type II 5'-deiodinase and inhibits liver type I 5'-deiodinase activity (Pezzi et al., 2003). Therefore, a changed local $\mathrm{T}_{3}$ production in the mammary gland might also be an important factor for decreased milk production during the NEB induced by feed restriction.

Plasma leptin decreased in early lactating dairy cows as well as in R cows. Block et al. (2001) attributed the postpartum decrease in plasma leptin concentration to the state of NEB caused by the initiation of lactation. Increased concentration of $\mathrm{GH}$ and decreased plasma insulin concentration coincide with the onset of NEB and the decrease in plasma leptin in periparturient and underfed cows (Block et al., 2001, 2003). The decrease of plasma leptin is associated with an enhanced appetite (Ingvartsen and Andersen, 2000). However, during the period of NEB postpartum, energy requirements could not be met in spite of increasing feed intake because of limited capacity of ruminal fermentation. Furthermore, leptin is partly responsible for maintaining $\mathrm{T}_{4}$ levels (Vernon et al., 2002) and, therefore, hypoleptinemia may have been partially responsible for the hypothyroid state during periods of NEB.

The state of hypoinsulinemia in early lactating dairy cows is a major regulatory element in the adaptive system around parturition to support lactation (Butler et al., 2003). The decreased plasma insulin concentrations during the NEB in early lactation in our study decreased glucose uptake in insulin-responsive tissues (e.g., muscle and adipose tissue) and enabled more glucose uptake of the non-insulin-responsive mammary gland (Bauman and Elliot, 1983) via insulinindependent glucose transporters 1 and 3 (Zhao et al., 1996). Furthermore, insulin is hypothesized to be a key signal regulating the coupling of the somatotropic axis (Butler et al., 2003). The deliberately induced NEB study was accompanied by a protein deficiency, which would explain the rather small decrease in plasma insu- lin concentration compared with the decrease in early lactation (Ronge et al., 1988; Kreuzer et al., 1991). The mRNA abundance of hepatic INSR was highest during the NEB in early lactation and also in cows during the deliberately induced NEB. It appears that the low plasma insulin level causes an upregulation of the INSR, perhaps to maintain the insulin function in the liver, while maximizing nutrient supply to the mammary gland. In dairy cows selected for high milk production, peri- and postparturient insulin resistance plays a pivotal role both in the adaptation to the NEB and in the pathogenesis of some NEB-related diseases, such as excessive lipid accumulation in the liver (Ohtsuka et al., 2001; Grummer, 2008) and ketosis (Hove, 1978). The RQUICKI has been introduced by Holtenius and Holtenius (2007) to detect mild differences in insulin resistance in healthy, lactating dairy cows. Health disorders attributed to the NEB (e.g., ketosis, displacement of the abomasum, or laminitis) were reported to be closely related to the insulin resistance state in dairy cows around parturition (Kerestes et al., 2009). In the study of Kerestes et al. (2009), however, the RQUICKI was not correlated with insulin resistance in dairy cows with ketosis or puerperal metritis. In accordance with Kerestes et al. (2009), our study showed a decrease of the RQUICKI during NEB around parturition, indicating insulin resistance during early lactation and thereby facilitating nutrient uptake by the mammary gland. The RQUICKI remained almost unchanged during the deliberately induced NEB in later lactation (i.e., an insulin resistance did not occur during this period). Stengärde et al. (2010) found the RQUICKI to be a more sensitive method for detection of metabolic imbalances than the individual parameters (NEFA, glucose, and insulin) used for the calculation of the index. As genetically high-yielding dairy cows show a higher insulin resistance than do low-yielding dairy cows (Chagas et al., 2009), the RQUICKI might also be related to differences in productivity.

\section{CONCLUSIONS}

Early lactating cows experienced marked changes in the endocrine system and hepatic gene expression in response to the NEB p.p. The deliberately induced NEB at around 100 DIM was unlike early lactation, showing only small alterations of the studied parameters. It was surprising that regulatory mechanisms responded more strongly during the NEB in early lactation when compared with responses during the following deliberately induced NEB by feed restriction, which produced a greater NEB than that of early lactation. Therefore, endocrine and hepatic regulation in dairy cow adaptation to 2 stages of an NEB are different. It seems the 
IGFBP, mainly IGFBP-3, are crucial factors to compensate for differences of adaptive changes during NEB in early and midlactation dairy cows. In addition, the development of an insulin resistance to enforce selective nutrient uptake by the mammary gland is most pronounced during NEB in early lactation.

\section{ACKNOWLEDGMENTS}

The authors thank Yolande Zbinden and Claudine Morel (Veterinary Physiology, University of Bern, Switzerland) for the blood plasma and gene expression analyses. The mentoring of the Graduate School (Graduate Center Weihenstephan) of the Technical University of Munich (TUM-GS, Freising-Weihenstephan, Germany) during the doctoral study of J. Gross is acknowledged.

\section{REFERENCES}

Bauman, D. E., and W. B. Currie. 1980. Partitioning of nutrients during pregnancy and lactation: A review of mechanisms involving homeostasis homeorhesis. J. Dairy Sci. 63:1514-1529.

Bauman, D. E., J. H. Eisemann, and W. B. Currie. 1982. Hormonal effects on partitioning of nutrients for tissue growth: Role of growth hormone and prolactin. Fed. Proc. 41:2538-2544.

Bauman, D. E., and J. M. Elliot. 1983. Control of nutrient partitioning in lactating ruminants. Pages 437-468 in Biochemistry of Lactation. T. B. Mepham, ed. Elsevier Science Publishers, Amsterdam, the Netherlands.

Baxter, R. C. 1993. IGF binding protein-3 and the acid-labile subunit: Formation of the ternary complex in vitro and in vivo. Adv. Exp. Med. Biol. 343:237-244.

Block, S. S., W. R. Butler, R. A. Ehrhardt, A. W. Bell, M. E. Van Amburgh, and Y. R. Boisclair. 2001. Decreased concentration of plasma leptin in periparturient dairy cows is caused by negative energy balance. J. Endocrinol. 171:339-348.

Block, S. S., R. P. Rhoads, D. E. Bauman, R. A. Ehrhardt, M. A. McGuire, B. A. Crooker, J. M. Griinari, T. R. Mackle, W. J. Weber, M. E. Van Amburgh, and Y. R. Boisclair. 2003. Demonstration of a role for insulin in the regulation of leptin in lactating dairy cows. J. Dairy Sci. 86:3508-3515.

Blum, J. W., P. Kunz, H. Leuenberger, K. Gautschi, and M. Keller. 1983. Thyroid hormones, blood plasma metabolites and haematological parameters in relationship to milk yield in dairy cows. Anim. Prod. 36:93-104.

Bradford, B. J., and M. S. Allen. 2008. Negative energy balance increases peripheral ghrelin and growth hormone concentrations in lactating dairy cows. Domest. Anim. Endocrinol. 34:196-203.

Breier, B. H. 1999. Regulation of protein and energy metabolism by the somatotropic axis. Domest. Anim. Endocrinol. 17:209-218.

Butler, S. T., A. L. Marr, S. H. Pelton, R. P. Radcliff, M. C. Lucy, and W. R. Butler. 2003. Insulin restores GH responsiveness during lactation-induced negative energy balance in dairy cattle: Effects on expression of IGF-I and GH receptor 1A. J. Endocrinol. 176:205-217.

Carriquiry, M., W. J. Weber, S. C. Fahrenkrug, and B. A. Crooker. 2009. Hepatic gene expression in multiparous Holstein cows treated with bovine somatotropin and fed n-3 fatty acids in early lactation. J. Dairy Sci. 92:4889-4900.

Chagas, L. M., M. C. Lucy, P. J. Back, D. Blache, J. M. Lee, P. J. S. Gore, A. J. Sheahan, and J. R. Roche. 2009. Insulin resistance in divergent strains of Holstein-Friesian dairy cows offered fresh pasture and increasing amounts of concentrate in early lactation. J. Dairy Sci. 92:216-222.
Chilliard, Y., C. Delavaud, and M. Bonnet. 2005. Leptin expression in ruminants: Nutritional and physiological regulations in relation with energy metabolism. Domest. Anim. Endocrinol. 29:3-22.

Fenwick, M. A., R. Fitzpatrick, D. A. Kenny, M. G. Diskin, J. Patton, J. J. Murphy, and D. C. Wathes. 2008. Interrelationships between negative energy balance (NEB) and IGF regulation in liver of lactating dairy cows. Domest. Anim. Endocrinol. 34:31-44.

Gross, J., H. A. van Dorland, R. M. Bruckmaier, and F. J. Schwarz. 2011. Performance and metabolic profile of dairy cows during a lactational and deliberately induced negative energy balance with subsequent realimentation. J. Dairy Sci. 94:1820-1830.

Grummer, R. R. 2008. Nutritional and management strategies for the prevention of fatty liver in dairy cattle. Vet. J. 176:10-20.

Holtenius, P., and K. Holtenius. 2007. A model to estimate insulin sensitivity in dairy cows. Acta Vet. Scand. 49:29-31.

Hove, K. 1978. Insulin secretion in lactating cows: Responses to glucose infused intravenously in normal, ketonemic, and starved animals. J. Dairy Sci. 61:1407-1413.

Ingvartsen, K. L., and J. B. Andersen. 2000. Integration of metabolism and intake-regulation: A review focusing on periparturient animals. J. Dairy Sci. 83:1573-1597.

Kelley, K. M., Y. Oh, S. E. Gargosky, Z. Gucev, T. Matsumoto, V. Hwa, L. Ng, D. M. Simpson, and R. G. Rosenfeld. 1996. Insulinlike growth factor-binding proteins (IGFBPs) and their regulatory dynamics. Int. J. Biochem. Cell Biol. 28:619-637.

Kerestes, M., V. Faigl, M. Kulcsár, O. Balogh, J. Földi, H. Fébel, Y. Chilliard, and G. Huszenicza. 2009. Periparturient insulin secretion and whole-body insulin responsiveness in dairy cows showing various forms of ketone pattern with or without puerperal metritis. Domest. Anim. Endocrinol. 37:250-261.

Kobayashi, Y., C. K. Boyd, C. J. Bracken, W. R. Lamberson, D. H. Keisler, and M. C. Lucy. 1999. Reduced growth hormone receptor (GHR) messenger RNA in liver of periparturient cattle is caused by a specific down-regulation of GHR $1 \mathrm{~A}$ that is associated with decreased insulin-like growth factor-I. Endocrinology 140:39473954.

Kobayashi, Y., C. K. Boyd, B. L. McCormack, and M. C. Lucy. 2002. Reduced IGF-I after feed restriction in lactating dairy cows is independent of changes in growth hormone receptor 1A. J. Dairy Sci. 85:748-754.

Kreuzer, M., M. Kirchgessner, and J. W. Blum. 1991. Concentrations of hormones and metabolites in blood plasma of cows during and subsequent to different crude protein supply. J. Anim. Physiol. Anim. Nutr. (Berl.) 65:11-20.

Liefers, S. C., R. F. Veerkamp, M. F. W. te Pas, C. Delavaud, Y. Chilliard, and T. van der Lende. 2003. Leptin concentrations in relation to energy balance, milk yield, intake, live weight, and estrus in dairy cows. J. Dairy Sci. 86:799-807.

Lucy, M. C., H. Jiang, and Y. Kobayashi. 2001. Changes in the somatotropic axis associated with the initiation of lactation. J. Dairy Sci. 84(E Suppl.):E113-E119.

McCarthy, S. D., S. T. Butler, J. Patton, M. Daly, D. G. Morris, D. A. Kenny, and S. M. Waters. 2009. Differences in the expression of genes involved in the somatotropic axis in divergent strains of Holstein-Friesian dairy cows during early and mid lactation. J. Dairy Sci. 92:5229-5238.

Meier, S., P. J. S. Gore, C. M. E. Barnett, R. T. Cursons, D. E. Phipps, K. A. Watkins, and G. A. Verkerk. 2008. Metabolic adaptations associated with irreversible glucose loss are different to those observed during under-nutrition. Domest. Anim. Endocrinol. 34:269-277.

Ohtsuka, H., M. Koiwa, A. Hatsugaya, K. Kudo, F. Hoshi, N. Itoh, H. Yokota, H. Okada, and S. Kawamura. 2001. Relationship between serum tumor necrosis factor-alpha activity and insulin resistance in dairy cows affected with naturally occurring fatty liver. J. Vet. Med. Sci. 63:1021-1025.

Orlowski, C. C., A. L. Brown, G. T. Ooi, Y. W.-H. Yang, L. Y.H. Tseng, and M. M. Rechler. 1990. Tissue, developmental, and metabolic regulation of messenger ribonucleic acid encoding a rat insulin-like growth factor-binding protein. Endocrinology 126:644-652. 
Perseghin, G., A. Caumo, M. Caloni, G. Testolin, and L. Luzi. 2001. Incorporation of the fasting plasma FFA concentration into QUICKI improves its association with insulin sensitivity in nonobese individuals. J. Clin. Endocrinol. Metab. 86:4776-4781.

Pezzi, C., P. A. Accorsi, D. Vigo, N. Govoni, and R. Gaiani. 2003. 5 -Deiodinase activity and circulating thyronines in lactating cows. J. Dairy Sci. 86:152-158.

Radcliff, R. P., B. L. McCormack, D. H. Keisler, B. A. Crooker, and M. C. Lucy. 2006. Partial feed restriction decreases growth hormone receptor $1 \mathrm{~A}$ mRNA expression in postpartum dairy cows. J. Dairy Sci. 89:611-619.

Renaville, R., M. Hammadi, and D. Portetelle. 2002. Role of somatotropic axis in the mammalian metabolism. Domest. Anim. Endocrinol. 23:351-360.

Ronge, H., J. Blum, C. Clement, F. Jans, H. Leuenberger, and H. Binder. 1988. Somatomedin C in dairy cows related to energy and protein supply and to milk production. Anim. Prod. 47:165-183.

Sauerwein, H., U. Heintges, M. Hennies, T. Selhorst, and A. Daxenberger. 2004. Growth hormone induced alterations of leptin serum concentrations in dairy cows as measured by a novel enzyme immunoassay. Livest. Prod. Sci. 87:189-195.

Stengärde, L., K. Holtenius, M. Tråvén, J. Hultgren, R. Niskanen, and U. Emanuelson. 2010. Blood profiles in dairy cows with displaced abomasum. J. Dairy Sci. 93:4691-4699.

Thissen, J.-P., J.-M. Ketelslegers, and L. E. Underwood. 1994. Nutritional regulation of the insulin-like growth factors. Endocr. Rev. 15:80-101.

van Dorland, H. A., S. Richter, I. Morel, M. G. Doherr, N. Castro, and R. M. Bruckmaier. 2009. Variation in hepatic regulation of metabolism during the dry period and in early lactation in dairy cows. J. Dairy Sci. 92:1924-1940.
Vandehaar, M. J., B. K. Sharma, and R. L. Fogwell. 1995. Effect of dietary energy restriction on the expression of insulin-like growth factor-I in liver and corpus luteum of heifers. J. Dairy Sci. 78:832-841.

Vernon, R. G., R. G. P. Denis, A. Sorensen, and G. Williams. 2002. Leptin and the adaptations of lactation in rodents and ruminants. Horm. Metab. Res. 34:678-685.

Vicari, T., J. J. G. C. van den Borne, W. J. J. Gerrits, Y. Zbinden, and J. W. Blum. 2008. Postprandial blood hormone and metabolite concentrations influenced by feeding frequency and feeding level in veal calves. Domest. Anim. Endocrinol. 34:74-88.

Vicini, J. L., F. C. Buonomo, J. J. Veenhuizen, M. A. Miller, D. R. Clemmons, and R. J. Collier. 1991. Nutrient balance and stage of lactation affect responses of insulin, insulin-like growth factors I and II, and insulin-like growth factor-binding protein 2 to somatotropin administration in dairy cows. J. Nutr. 121:1656-1664.

Windisch, W., M. Kirchgessner, and J. W. Blum. 1991. Hormones and metabolites in blood plasma of lactating dairy cows during and after energy and protein deficiency. J. Anim. Physiol. Anim. Nutr. (Berl.) 65:21-27.

Wook Kim, J., R. P. Rhoads, S. S. Block, T. R. Overton, S. J. Frank, and Y. R. Boisclair. 2004. Dairy cows experience selective reduction of the hepatic growth hormone receptor during the periparturient period. J. Endocrinol. 181:281-290.

Zhao, F. Q., W. M. Moseley, H. A. Tucker, and J. J. Kennelly. 1996. Regulation of glucose transporter gene expression in mammary gland, muscle, and fat of lactating cows by administration of bovine growth hormone and bovine growth hormone-releasing factor. J. Anim. Sci. 74:183-189. 